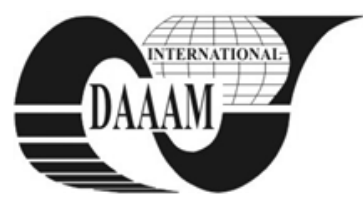

Annals of DAAAM for 2011 \& Proceedings of the 22nd International DAAAM Symposium, Volume 22, No. 1, ISSN 1726-9679 ISBN 978-3-901509-83-4, Editor B. Katalinic, Published by DAAAM International, Vienna, Austria, EU, 2011 Make Harmony between Technology and Nature, and Your Mind will Fly Free as a Bird Annals \& Proceedings of DAAAM International 2011

\title{
CORPORATE GOVERNANCE AND MANAGERIAL PERFORMANCE IN THE FINANCIAL SECTOR: A PROPOSAL FOR A NEW METHOD OF SCORING
}

\author{
DRAGOTA, I[ngrid] - M[ihaela] \& STANCU, M[ihaela]
}

\begin{abstract}
The study is a proposal of a new scoring system to analyse the degree of compliance with the most important corporate governance principles using a sample of more than 150 companies from various countries around the world. The thirteen mechanisms were selected from the principles included in different national or international Codes of Corporate Governance. The analysis explores especially banking and insurance industries and the results can be better understood taking into account the particularities of each type of financial system.
\end{abstract}

Key words: corporate governance, scoring analysis, insurance and banking sectors, transparency, managerial performance

\section{INTRODUCTION AND LITERATURE REVIEW}

The current financial crisis re-brings to light the debates on corporate governance principles, in a period when the Board of Directors of many major companies was accused of carrying out activities that have significantly increased their general risk exposure. In this study, due to the importance for both investors and firms, the corporate governance mechanisms were used for a new proposal of scoring analysis and the evaluation grid was applied on a sample of 155 companies from banking, insurance and energy (oil and conglomerates) industries. Only the internal mechanisms of these firms were analyzed due to the fact that they can be quantified, as opposed to external ones that are not directly observable. In the study, the main models of governance were considered: Anglo-Saxon, European, Asian and Islamic. Their characteristics are the result of historical developments, specific to each country (see Allen \& Gale, 2000, Dragota et al. 2008, among others). Every financial system is connected with the legal system of that country. Many international studies which have linked the law and finance through corporate governance have focused on differences in legal systems across countries and legal families and the effects on different corporate outcomes (see La Porta et al., 1998; Beck et al., 2003; Klapper \& Love, 2004 etc.). Generally, a company must respect four principles of corporate governance: transparency and reporting, accountability, fairness and responsibility. Usually, the Codes/Guidelines of corporate governance place in the forefront the protection of the shareholders and creditors by the actions of managers and controlling shareholders (La Porta et al., 1999; La Porta et al., 2000; Priya \& Siems, 2007; Siems, 2008, Goergen \& Renneboog, 2008 etc.). The corporate governance codes of the developed countries (Sarbanes-Oxley Act for U.S., Combine Code for UK, etc.), and those provide by different international bodies such as OECD, emphasize the responsibilities of various board committees and subcommittees, which must act to protect the interests of all stakeholders. A lot of empirical studies analysed the board structure and its performances and the impact of good governance of a firm (O'Reilly III \& Main, 2007; Linck et al., 2008; Bruno \& Claessens, 2010; Brick \& Chidambaran, 2010, Engel et al., 2010; Ammann et al., 2011; Faleye et al., 2011; Platt \& Platt, 2011). Moreover, the CEO and the Chairman of the Board should always be different (Cadbury, 1992; Financial Reporting Council, 2010/2011;
Stuart, 2003; Coombes \& Wong, 2004; Kakabadse et al., 2010; Dey et al. 2011, among others). Whether the company has single or dual management system, the Codes recommends the establishment of at least three sub-committees, namely: Audit, Nominations and Remuneration Committee. Development of these themes can be found in works of Mallin, 2004; Keasey et al., 2005; Plessis et al., 2011, among others. Both Board and sub-committees members should include independent nonexecutive directors, with the overall aim to contribute to strategic and business development. These important mechanisms of corporate governance and others are included in the scoring system and the results are presented in the following section. Section 3 concludes the study.

\section{METHODOLOGY AND RESULTS}

The scoring system used publicly available information from the web pages of the companies (see "file 1" on http://www.cercetarepensii.ase.ro/index_files/links.htm).

Thirteen mechanisms of corporate governance were enclosed in the scoring system, with scores ranged from 1 to 5 , depending on the degree of implementation of each mechanism. In order to compare the results between companies, based on their financial system, a sum and an average of these scores were determined. The maximum value is 65 , i.e. $13 \times 5$ mechanisms and the maximum average value is 5 . Therefore, the scoring system is as follows: 0 if the company does not have the mechanism; 1 if the company has this mechanism in a very small extent; 2 if the company has this mechanism in a small extent; 3 if the company has this mechanism in a moderate extent; 4 if the company has this mechanism in a large extent; 5 if the company has this mechanism in a very large extent. According to these mechanisms a company has: 1. a code of corporate governance or guidelines, code of ethics etc. and complies with the national codes of corporate governance; 2 . good relationships with the investors, it organises regular meetings etc.; 3. periodic financial reports (transparency); 4. independent non-executive directors; 5. the Chairman and CEO, not the same person; 6. an Audit Committee with independent non-executive members, and their names are publicly known; 7. a Remuneration Committee with independent non-executive members, and their names are known; 8. a Nomination Committee with independent nonexecutive members, and their names are known; 9. a Financial Committee; 10. a Risk Management Committee; 11. other committees (technology, stakeholder relations, governance, etc.); 12. social responsibility programs; 13 . regular publications about meetings with shareholders/ stakeholders, events, web casts, email alert, with a clear website with useful information for the investors. The results of our analysis were presented in five tables, which are posted on the website of our research project: http://www.cercetarepensii.ase.ro/index.htm.

The U.S. case. All companies are from the financial sector with the following structure: 22 insurance companies (63\%), 12 banks and financial services companies $(35 \%)$ and an investment company (2\%). All companies have their own code of governance and they comply with SEC rules. They have 
special sections in their website to provide information to the investors. All companies fulfilled the transparency criterion because they published annual reports, easily to be understood by the investors. In almost all cases, due to strict regulations, the majority of board members were independent non-executive directors. Moreover, more than $30 \%$ companies from our sample had different people serving as chairman and CEO, with 6 insurance companies (two thirds of all insurance companies), and the remaining 5 are banks. All companies from the sample had available, on their website, the key responsibilities for the Audit Committee. Their websites also provided details of name, age etc. of the directors who are members of these Committees, except one company, which received a score of $3.40 \%$ of the analysed companies had a Financial Committee and over $46 \%$ of them are insurance companies. 14 companies have a special Risk Committee, with 5 insurance companies. The rest of them did not have such committee. In most cases, banks have obtained high scores and the insurance companies were at the opposite pole. A detailed analysis (including Energy-Oil companies) can be found in Table 1 from "file 2", posted on our abovementioned website.

The U.K. case. The sample contained 25 companies with the following structure: 9 insurance companies (36\%), 11 banks and financial services companies (44\%), 2 investment companies (8\%) and 3 Energy-Oil ones (12\%). As a general conclusion, it may be stated that all companies had a good governance system because, from many years, strict regulations have been implemented. Almost all companies from the sample (23) had all three mandatory sub-committees. A single insurance company had additionally a Financial Committee. More than $50 \%$ of the analysed companies had Risk Management Committees, more than in the U.S. case, with 4 insurance companies. The rest of them are banks or financial services companies. 16 companies have also other subcommittees: 5 of them are insurance companies and 7 are banks or financial services companies. A similar analysis was made for the Energy-Oil companies and the results are in Table 2 from "file 2", posted on our website. The average score for UK is 4.22 , slightly above the U.S score of 4.10 .

The Continental Europe case. The analysis included 35 companies from 10 countries, with 6 insurance companies (20\%), 19 banks and financial services companies (55\%), 1 conglomerate and 9 Energy-Oil companies (25\%). Banks and insurance companies have obtained the highest scores. 32 companies had a Code of best practices and more than $80 \%$ had different people serving as chairman and CEO. All the insurance companies had the three required sub-committees. All companies from the sample had an Audit Committee, 2 of them did not have a Remuneration Committee and 4 did not have the Nomination one. Only 7 companies have a Financial Committee ( 2 insurance companies, 2 banks and 2 Energy-Oil companies), and 23 companies have the Risk Management Committee (over $50 \%$ of the total, above the U.S. sample), with 3 insurance companies and 16 banks. 24 companies (two thirds of the total sample) had other sub-committees, too. A similar analysis was made for the Energy-Oil companies (see Table 3). The average score is 4.26 , very close to U.S. and U.K.

The Asian case. The sample included 35 companies from China, Japan, India and South Korea with the following structure: 5 insurance companies $(15 \%), 11$ banks and financial services companies (32\%), 3 Energy-Oil companies (8\%) and 16 conglomerates $(45 \%)$. The analysis proved that only 8 companies have not fulfilled the criterion to have a Code of Corporate Governance. 33 companies had different people serving as chairman and CEO and all insurance companies fulfilled this criterion. All banks and financial services companies had the three mandatory sub-committees. Also, all companies have an Audit Committee and 27 of them received the maximum score for this mechanism. Regarding the Remuneration Committee, all insurance companies, banks and financial services companies have this Committee, except one; the same company did not have the Nomination Committee. 23 companies obtained the score 5 , and 4 companies did not have this committee. 22 companies had a Nomination Committee and 6 of them did not have this committee, with 2 insurance companies. No Asian company had a Financial Committee. Almost all banks had the Risk Committee and only 2 of 5 insurance companies had this type of sub-committee. Only one insurance company had other sub-committees. A similar analysis was made for the Energy-Oil companies (see Table 4). The average score is 3.93, well below the average of Europe of 4.26 , with a similar governance model.

The Islamic countries case. Mainly banks and oil companies were analyzed due to the specific economic activities for these countries. Thus, 25 companies were chosen from Turkey, UAE, Kuwait, and Egypt with the following structure: one insurance company (4\%), 17 banks $(68 \%), 4$ conglomerates $(16 \%)$ and 3 Energy-Oil companies (12\%). All companies had different people serving as chairman and CEO. The highest scores were obtained by banks and conglomerates. The lowest score was obtained by the insurance company because it did not have a Code of Corporate Governance, and had only the Audit Committee. All companies had Audit Committees, 11 did not have a Remuneration Committee, 13 did not have a Nomination one, and only 2 had a Financial Committee (those who obtained the maximum score). 5 companies did not have other committees. A similar analysis was made for the Energy-Oil, banking sector and for conglomerate companies and the results are presented in Table 5 , due to page restrictions. After the scoring system was applied, the average score obtained by the Islamic countries was 3.90 , very close to Asia case.

\section{CONCLUSIONS AND FUTURE RESEARCH}

The study revealed that companies from countries from the Anglo-Saxon and European financial systems fulfilled the corporate governance principles, based on a well planned legislation, and consequently they had the highest scores. Generally, banks and insurance companies obtained the highest scores, especially those from Europe and US. Regarding the companies from Asian and Islamic financial systems, the insurance companies fulfil corporate governance criteria only partially due to more relaxed laws regarding the corporate governance. As future research we must extend the database and the scoring system can be more refined.

\section{ACKNOWLEDGEMENTS}

This work was supported by CNCSIS - UEFISCDI, project number PNII - IDEI code 1831/2008.

\section{REFERENCES}

Dragotă, V.; Dragotă, M.; Braşoveanu, L.; Stoian, A.; Lipară, C. \& Cetean, E. (2008). Pieţe şi sisteme financiare (Financial markets and financial systems), ASE Publisher, ISBN 978-973-594-998-3, Bucharest

La Porta, R.; Lopez-de-Silanes, F.; Shleifer, A. \& Vishny, R. (2000). Investor protection and corporate governance, Journal of Financial Economics, Vol.58, No. 1-2, 3-27, ISSN 0304-405X

Brick, I.E. \& Chidambaran, N.K. (2010). Board meetings, committee structure, and firm value, Journal of Corporate Finance, Vol. 16, No. 4, (September 2010) 533-553, ISSN 0929-1199

Dey, A.; Engel, E. \& Liu, X. (2011). CEO and board chair roles: To split or not to split? Journal of Corporate Finance, In Press 12 September 2011, ISSN 0929-1199

Bruno, V. \& Claessens, S. (2010). Corporate governance and regulation: Can there be too much of a good thing? Journal of Financial Intermediation, Vol. 19, No. 4 (October 2010) 461-482, ISSN 1042-9573 